REVISTA ARA N ${ }^{\circ} 7$. VOLUME 7 . PRIMAVERA+VERÃO 2019 • GRUPO MUSEU/PATRIMÔNIO FAU-USP

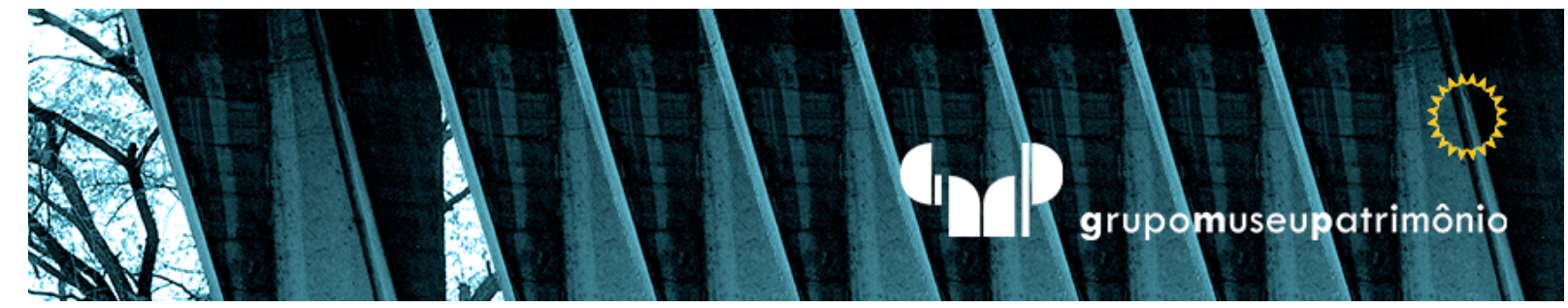

\title{
Desafios em expor, limites da autoria
}

\author{
Chalenges in exhibihitons, \\ authorship's boundaries
}

\author{
Desafíos en exponer, \\ límites de autoría
}

\begin{abstract}
Amanda Saba Ruggiero
Universidade de São Paulo, Faculdade de Arquitetura e Urbanismo, Pós-Doutoranda e Pesquisadora do Grupo Museu Patrimônio. São Paulo, Brasil.amandaruggiero@usp.br
\end{abstract}




\title{
Resumo
}

Da "morte do autor" (R. Barthes) ao questionamento do "o que é um autor?" (Michel Foucault, 1969), debate-se amplo horizonte a respeito da história das ideias e da cultura material, desde abordagens histórico-sociais à produção literária. A relevância do texto em versões revisitadas e ampliadas, como as do historiador Roger Chartier e o filósofo Giorgio Agamben, incita reflexões sobre a função-autor à luz da contemporaneidade. Ao pensar sobre pequenos deslocamentos e desvios da vida hodierna, busca-se neste artigo aprofundar reflexões para outras linguagens, como a escrita, práticas expositivas e relações entre instituições, espaços, autoria, narrativas e curadoria. A propósito de encontrar corpo a incitar e conclamar alguma profanação, a exposição pensada como um dispositivo estrutura bases para o objeto investigado.

Palavras-Chave: Autor. Função-autor. Curadoria. Exposição.

\section{Resumen}

Desde la "muerte del autor" (R. Barthes) hasta la pregunta "¿quién es un autor?" (Michel Foucault, 1969), se debate un amplio horizonte sobre la historia de las ideas y la cultura material, desde temas sociales para la producción literaria. La relevancia del texto en versiones revisitadas y ampliadas, como las del historiador Roger Chartier y el filósofo Giorgio Agamben, incita reflexiones sobre la función del autor a la luz de los tiempos contemporáneos. Pensando en pequeños desplazamientos y desviaciones de la vida actual, este artículo busca profundizar las reflexiones para otros idiomas, como la escritura, las prácticas expositivas y las relaciones entre instituciones, espacios, autoría, narrativas y curaduría. Con el fin de encontrar un cuerpo para incitar y proclamar alguna profanación, la exposición pensada como un dispositivo construye bases para el objeto investigado.

Palavras-chave: Autor. Autor de la función. Curador. Exposición.

\begin{abstract}
From the "death of the author" (R. Barthes) to the question of "who is an author?" (Michel Foucault, 1969), a broad horizon is debated regarding the history of ideas and material culture, from social historic issues to literacy. The relevance of the text in revisited and expanded versions, as by the historian Roger Chartier and the philosopher Giorgio Agamben, incites reflections on the author-function in the light of contemporary times. Thinking about small displacements and deviations from today's life, this article seeks to deepen reflections for other languages, such as writing, expository practices and relations between institutions, spaces, authorship, narratives and curatorship. In order to find a body to proclaim some "Profanação", the exposition as a dispositive builds bases for the investigated object.
\end{abstract}

Keywords: Author. Author function. Curatorship. Exhibition. 


\section{DESAFIOS EM EXPOR, LIMITES DA AUTORIA}

pensamento crítico em períodos de posicionamentos extremos e
polarizações surge como caminho viável a evitar acachapantes forças da alienação. O exercício reflexivo requer aptidões e esforços em selecionar temas e assuntos de um todo, para então aprimorar habilidades perceptivas sobre desvios, muitas vezes sutis, da realidade cotidiana. As formulações contidas no artigo visam pensar e localizar algumas disfunções que subvertem procedimentos por vezes naturalizados. Ao centralizar atenção nas ações curatoriais, procura desvendar operações e práticas alocadas em instituições de arte, em especial nos museus. As ponderações elaboradas a respeito de autoria, presença do autor e função-autor, em materialidades e subjetividades, são embasadas pelos textos de Michel Foucault (função autor), Roger Chartier (materialidade), Giorgio Agamben (gesto e nexo) e configuram fundamentos teóricos para elaborar pensamento crítico sobre a curadoria, instituição e exposições.

Por meio de depoimentos em entrevistas, posturas e ações mapeadas, encontram-se desvios de uma lógica imperativa, predominante em locais 
consagrados $^{1}$ ou não, sendo necessário iluminar o que pretende inverter a ordem daquilo que persiste. A estrutura a seguir, organizada em três eixos, inicialmente versa sobre o conceito da função-autor proferido por M. Foucault, e sugere deslocar-se em semelhante operação às instituições, curadorias e eventos expositivos. A exposição como um dispositivo ${ }^{2}$, segundo eixo, determina o conjunto de forças e ações que envolvem a elaboração e montagem de uma mostra, em narrativas visíveis e invisíveis concebidas por determinados segmentos. A materialidade, o nexo e o público, formam o terceiro eixo em que debatem-se as múltiplas faces do dispositivo e seus elementos, dentre eles o lugar do curador.

As considerações, por fim, vinculam o conceito de função-autor à existência de uma função-curadoria ou à uma função-instituição que muitas vezes acionam e direcionam o dispositivo, incidem sobre materialidades que se elegem e propagam, aliadas ao significado almejado e por vezes não alcançado. A pergunta deflagra a curadoria como gesto em situação normalizada, embora seu sentido, origem e propósito deveriam fundar-se na pesquisa, no domínio integro e crítico do conteúdo que se apresenta. Ao falar em curadoria, melhor seria se remeter às ideias, temas e objetos e não ao autor, ao curador. $\mathrm{Na}$ ausência do autor, ou na sua "borda inexpressiva" a obra acontece, ou seja, na experiência e na recepção. Os meios para compreender e avaliar a recepção, deveriam distanciar-se exclusivamente dos indicativos numéricos das catracas como exige a lógica financeira de consumo.

\footnotetext{
${ }^{1}$ O termo consagrado aqui se refere aos locais celebrados pelo sistema de arte, que são exaltados, gozam de certo prestigio, reconhecimento, fama e de alguma forma legitimam aquilo que se exibe, mostra, acolhe e salvaguarda.

2 Para Giorgio Agamben dispositivo é “(...) qualquer coisa que tenha de algum modo a capacidade de capturar, orientar, determinar, interceptar, modelar, controlar e assegurar os gestos, as condutas e os discursos dos seres viventes" (2009, p. 38 e 40).
} 


\section{Autor em função}

Michel Foucault ${ }^{3}$ interessado em interpretar as "condições de funcionamento das práticas discursivas" dedicou-se a pensar como o texto aponta para o autor ${ }^{4}$, figura externa e anterior ao texto. Para ele a escrita é como um jogo que sempre desafia o limite de suas regras e permite a abertura de "um espaço onde o sujeito da escrita está sempre a desaparecer" (1969, p.35), anunciando assim a morte do autor e o seu desaparecimento (John Searle e Roland Barthes). Nesta ação pretendida, há um espaço vazio deixado pelo desaparecimento do autor, e Foucault sugere seguir tais lacunas e examinar as funções que este espaço abre. O exame sobre quem escreve, enquanto o nome próprio transita do interior do discurso para o indivíduo real, o do autor caracteriza um modo de discurso, que recebe um certo estatuto em determinada cultura e um certo tempo. O nome do autor difere da função-autor. "A função-autor é, característica do modo de existência, de circulação e de funcionamento de alguns discursos no interior de uma sociedade" (1969, p.46).

A função-autor não se exerce de modo universal em todos os discursos e não coincide com a da ciência e da literatura (XVII e XVIII), não se forma de modo espontâneo, pela atribuição de uma fala a um indivíduo. O papel resulta de uma operação complexa, aproximações, exclusões, comparações, traços de ruptura e continuidade em determinadas épocas sobre certas narrativas. 0 que se define como função-autor do texto, pode-se deslocar para outros meios

3 Michel Foucault debate o que é um autor na conferência realizada na Société Française de Philosophie, na tarde de 22 de Fevereiro de 1969, publicado originalmente: Qu'est-ce qu 'un auteur?, anunciado como o autor de "Les Mots el les Choses" por J. Wahl (1888-1974), filósofo Francês, professor da Sorbonne 1936-1967, um seguidor de Henri Bergson que difundiu o pensamento Hegeliano na França nos anos 1930.

${ }^{4} \mathrm{M}$. Foucault assinala algumas invariáveis nas "regras da construção do autor", derivada da tradição cristã (São Jerônimo). O exemplo decorre da seguinte sistemática, se entre livros de um autor, houver um inferior, deve-se retirar este, o valor do autor como a coerência teórica ou conceitual, o estilo da escrita, e por fim o momento histórico (vida e acontecimentos) (1969, p.52). O autor é uma certa unidade de escrita. $O$ limite de seu argumento sobre o autor e o texto é conceituado por Foucault quando revela que seria necessário falar do que é a função autor na pintura, na música e nas técnicas, por exemplo. 
de linguagem e comunicação, como por exemplo para o curador $^{5}$, hoje posição muitas vezes em demasiada evidência de exposições, mostras, shows, galerias e museus. Ao falar sobre curadoria, a ênfase deveria estar no processo, resultado, forma, assunto, tema, objeto, artista ou a narrativa em voga e não exclusivamente sobre a figura pessoal do curador, num discurso particular e ponto de vista singular, bem como no papel que assume, muitas vezes em instituições, sendo o autor quem decide a última palavra. Não se trata de desqualificar ou minimizar o amplo trabalho daquele que seleciona, coordena, pensa, elabora tarefas complexas, a exigir múltiplas habilidades. Por ser um trabalho de natureza coletiva, executado por equipes, muitas vezes numa exposição inverte-se o objeto de interesse e sua potencialidade em comunicar, estar à mostra e compreensível ao público, um compromisso e um papel social, político e cultural. Assim como diz Foucault sobre o autor, o curador deveria desaparecer para que o tema sobrevenha de fato.

O historiador, professor e curador Barry Bergdoll ${ }^{6}$ assinalou a dificuldade em diagnosticar o fenômeno da "curadoria" e suas razões, por um lado há uma relação com a cultura da "amostragem" e da compulsão em escolher e selecionar coisas, e agora "curar" algo se tornou completamente banal, como um termo que significa somente fazer escolhas, elaborar uma lista, uma seleção. Uma imagem que se agrega ao termo da curadoria está ligada ao fato de concretizar eventos e ao mesmo tempo, inventar coisas para o público, assim destaca o aspecto atual da figura pública do curador. Porém, na etimologia da palavra "curador", o sentido de curadoria está ligado ao cuidado e à salvaguarda de uma coleção para futuras gerações, dado que

\footnotetext{
${ }^{5}$ Embora a origem da palavra esteja ligada ao ato de cuidar, tomar conta de algo, em meados do século VIII o termo, cunhado pela lei da antiga Roma, se expandiu para o sentido de guardar, conservar e cuidar de objetos de arte. O British Museum, por exemplo, desde o inicio teve funcionários designados curadores para cuidar do seu acervo e da coleção que se expandia. (Bergdoll, 2015)

6 Barry Bergdoll foi entrevistado pela autora em 2016, durante um programa de estágio no Museu de Arte Moderna de Nova York (MoMA-NY) e falou sobre diversos temas entre eles a curadoria, seu percurso pessoal, projetos realizados e futuros. A entrevista está publicada na Revista Risco n. 16(1), p.105-14. (Ruggiero, A.; Michel,L., 2018).
} 
historicamente o curador era uma pessoa muito mais dos bastidores, do que do "primeiro plano". Ao ser questionado sobre o tema, o historiador afirma que curadoria não é falar sobre curadores, mas sim debater conceitos, histórias, artistas, questões, incertezas e conteúdos atuais, ou seja, sobre alguma coisa longe do sempre apresentado. No trabalho da pesquisa certamente há escolhas, e um modo de arranjar as coisas para o engajamento do público, mas isto não significa se colocar à frente.

Historicamente os textos e livros passam a ter autor na medida em que este é capaz de ser punido e os discursos possuem conteúdo transgressor, vale dizer, a partir do momento em que o controle sobre o indivíduo é adotado pelo estado (Foucault, 1969, p.34). O historiador Roger Chartier $^{7}$ data este processo no inicio do século XVIII e não ao final como Foucault (2014, p.46). Ao descrever as práticas entre livreiros e autores em Londres e a formulação do copyright, o historiador discorreu sobre a desmaterialização da obra em formas diversas; igualmente assegura que a função-autor estava presente em período anterior à censura da Igreja e às formas do impresso, no século XV, na existência dos manuscritos por meio dos escribas. Chartier revisou a cronologia concebida por M. Foucault, atribuiu à presença da função-autor anterior e transferiu à materialidade do texto, e desta relação entre objeto físico e o leitor, novo sentido. Novos formatos produzem novos autores, assim forma e discurso são indissociáveis.

\footnotetext{
${ }^{7}$ Roger Chartier, em palestra na Sorbonne em 2000, aludiu à conferência de M. Foucault. Nesta revisita em pesquisa histórica do século XVIII ao XIV, e investiga as respostas dadas por Foucault à pergunta que ele mesmo definiu: o que é um autor? Chartier deixa de lado a sociologia do campo literário e se detém na análise de certos discursos no interior da sociedade que possuem a função-autor. Em referência ao texto de J.L. Borges, El Hacedor, demonstrou o jogo entre autor e ator, da figura pública a que se constrói o autor, ator dele mesmo, e cita Rousseau no século XVIII. Aponta três momentos na cronologia apresentada por Foucault, embora não houvesse uma intenção explicita em designar uma precisão histórica, mas em que corrige de certa forma as afirmativas e precisa com fatos as distinções sugeridas: vincular a função autor ao direito de propriedade (fim século XVIII); ao momento histórico em que os estados e as igrejas adotam o poder de vigiar e punir os autores e os textos transgressores, ao cruzamento (nomeia quiasma) entre enunciados científicos e as regras de identificação dos discursos literários.
} 
Neste sentido a exposição é uma nova leitura a cada evento e espectadores, a conexão entre o espaço e a narrativa, entre objetos que anunciam discursos em vizinhanças, eixos, posição, iluminação, e todos os elementos que desenham o espaço para o público, assim como textos e argumento, forma e o discurso caminham juntos, são inseparáveis, e sempre geram novos leitores e novos públicos a cada edição. A mesma mostra em montagem distinta, decorre em novas espacialidades e interpretações, coexistências em constante diálogo. Esta reciprocidade e interdependência para Giorgio Agamben ${ }^{8}$ encontra-se definida por um colocar-se em jogo, ressalte-se, no diálogo entre autor, obra e leitor.

Para Agamben o que garante a vida da obra está no gesto do autor, na presença de uma "borda inexpressiva". A figura do Arlequim, que interrompe a história, como num laço, depois volta a reatar o fio que se soltou, o gesto ilegível, o lugar que ficou vazio é o que torna possível a leitura. Autor e leitor põem-se em jogo no texto, a escritura é um dispositivo. 0 dispositivo ${ }^{9}$, para Agamben refere-se a "qualquer coisa que tenha de algum modo a capacidade de capturar, orientar, determinar, interceptar, modelar, controlar e assegurar os gestos, as condutas, as opiniões e os discursos dos seres viventes" (2009, p. 40). Ao pensar a função-autor em outras materialidades, em suporte espacial, neste caso as exposições, independente da escala, pessoas, forças, agentes, acordos, opiniões, pesquisas, criação e, portanto, capturas simbólicas criam significados, e configuram um dispositivo.

\footnotetext{
${ }^{8}$ No texto $O$ autor como gesto, Giorgio Agamben (2007, p.55) retoma o discurso proferido em 1969 no qual Michel Foucault centraliza sua abordagem na distinção entre duas noções frequentemente confundidas: o autor como indivíduo real e a função-autor. Foucault foca em aprofundar sobre a função-autor, e a partir desta lacuna Agamben tecerá suas considerações ao final do texto.

9 "Dispositivo" é um termo técnico decisivo no pensamento de Michel Foucault, segundo G. Agamben, ele se aproximou de uma definição em entrevista em 1977, publicada em Dit et ecrits; primeiro está relacionado a uma rede que se desencadeia entre elementos heterogêneos como instituições, edifícios, leis, discursos, tem função estratégica e se inscreve numa relação de poder, e a distinção do que é aceito ou não como cientifico, epistême. Giorgio Agamben, retoma a definição de M. Foucault e propõe alargamento. (2005)
} 


\section{A exposição como dispositivo}

Há um extenso quadro de tipologias expositivas, coletivas e individuais, temporárias e de grande duração para coleção própria, temática, cronológica, histórica entre outras. Variam em tamanho, formato, suportes, objetos, coleções, áreas - arte, design, arquitetura, desenhos, gravura, formas 3D, cinema, teatro, literatura, tecnologia. Acolhem livros, papéis, objetos industriais, automóveis e um universo material infinito. Neste artigo focalizamse as exibições de arte e arquitetura, circunscritas ao campo institucional dos museus. Bruce Altshuler ${ }^{10}$ descreveu categorias expositivas aplicadas àquelas de arte: como mostras organizadas por recortes históricos, temáticos, por categorias tradicionais como retrato, natureza morta, paisagem, com foco em alguma mídia em especifico ou técnicas como pintura, escultura, gravuras, performances, arte-conceitual; outras organizadas de modo cronológico ou temático. As exposições atuam e colaboram por suas funções, na promoção de artistas canônicos, a par de outros pouco conhecidos, por apresentar um emergente ou uma revisão de dada abordagem, em paralelo ao espaço em que são produzidas, como institucionais, comerciais, museológicas, municipais, corporativas, e por grupos de artistas ou individuais, como compradores, curadores, colecionadores e artistas (Altshuler, 2016, p.27).

Quando se desloca as reflexões sobre autoria para rede de circulação das $\operatorname{artes}^{11}$, surgem perguntas concernentes ao conceito de função-autor apontado por Foucault, à materialidade em Chartier e ao que se refere ao gesto como nexo, de Agamben. Como se afere a função-autor para uma

\footnotetext{
10 Bruce Altshuler é diretor do programa de estudos museológicos da New York University. Professor, já dirigiu museus e galerias como o Museu Isamu Noguchi-NY. Publicou inúmeros artigos sobre arte moderna e contemporânea e livros, entre eles uma coletânea de exposições relevantes em dois volumes: Salon to Biennial-Exhibitions That Made Art History, Volume I: 1863-1959 (Phaidon Press, 1998); e Biennials and Beyond: Exhibitions that Made Art History, Volume II: 1962-2002 (Phaidon Press, 2013).

${ }^{11}$ Sistema de circulação das artes engloba amplo conjunto com realce para artista, instituição, curador, conservador, restaurador, educador, jornalista, museólogo, design, arquiteto, historiador, crítico, professor, colecionador, marchand e mercado em geral. Estes incluem aqueles que financiam, cobram, emprestam, calculam riscos e juros.
} 
exposição, o estatuto se transferiu do artista para o curador? A função autor está na instituição, no curador ou no público? Acrescento ainda, nas transações comerciais? Em uma mostra coletiva, se estabelece uma nova função autor definida pelo tema, questões e pela narrativa da curadoria? Em que medida o curador instaura, desenha e manipula a circulação e o funcionamento do discurso? $\mathrm{O}$ artista ou a instituição direcionam leituras e molduram sua função? Sem público diversificado como justificar o dispêndio de recursos variados?

No Prefácio do livro El arte del siglo XX en sus exposiciones. 1945-2007, por meio da ampla pesquisa sobre as exposições do século XX, Anna Maria Guasch procurou demonstrar a mudança de paradigmas que se deslocou de um "discurso da criação", colado à figura do artista e seu trabalho individual, para o "discurso da recepção", protagonizado não somente pelos criadores, mas também pelas instituições, curadores, diretores de museus, críticos e demais agentes do denominado "sistema da arte". Este que não se define somente por feições formais e inerentes à natureza artística, mas por aspectos econômicos, sociais e culturais, nas suas palavras: "como planteó George Dickie en The Art Circle (1984), que una obra de arte es "arte" a causa de la posición que ocupa en el marco de las prácticas culturales" (2009, p.13). De modo paralelo, a posição da instituição e a do curador neste conjunto de "práticas culturais" aliam-se nas plataformas de poder para definir e antecipar expectativas dos receptores. ${ }^{12}$

Um exemplo da função instituição poderia ser atribuída ao Museu de Arte Moderna de Nova York (MoMA-NY), dado reconhecimento mundial pelo acolhimento, difusão, salvaguarda e promoção do seu acervo de arte moderna que abrange inúmeros suportes desde pintura, escultura, fotografia, filme, gravura, desenho, arquitetura, design, mídias digitais e performances. 0

\footnotetext{
${ }^{12}$ A tese de Doutorado Exposições de arte brasileira: um estudo de exposições como meio para a compreensão dos fundamentos e da recepção da arte contemporânea, de Adrienne O. Firmo, aborda de modo aprofundado questões similares, e debate a recepção e o estatuto do objeto artístico em distintos momentos do cenário nacional (Firmo, 2017).
} 
"poder" da instituição, como disse a curadora Paola Antonelli ${ }^{13}$ ajuda muitos designers e artistas dando visibilidade aos seus trabalhos, assim como perguntas, assuntos e temas. $O$ que se exibe no MoMA tem muita repercussão, há uma reputação e um alcance, neste sentido uma funçãoinstituição, que trabalha e se vale de marketing para manter esta projeção. Em seu depoimento, Antonelli ponderou que outras instituições com exposições e trabalhos mais pertinentes do que se produz no museu não têm o mesmo alcance. "O MoMA é uma instituição com liderança, para o bem e para o mal. Quando se produz algo aqui tem um impacto, e é melhor que não se perca a oportunidade", ao comentar a responsabilidade da curadoria. A burocracia e falta de transparência da instituição são, na sua fala, os aspectos negativos do museu. Ainda nesta entrevista, ela comentou sobre mostra que fez contrariada, pois não acreditava no tipo de design que promovia, "um ano perdido (...) há momentos que fazemos coisas que não gostamos porque elas funcionam bem para a instituição". Sem aprofundar em detalhes este episódio, seu descontentamento esteve em promover um tipo de produção autoral distante daquilo que qualifica o design, em seu ponto de vista a produção industrial, em larga escala, com baixo custo e ao alcance popular. Se de um lado a instituição pode ser um dispositivo que limita e direciona ações em acordo com suas premissas, há outras que permitem a liberdade e o aprofundamento de pesquisas em temáticas livres, muitas vezes desconexas com vantagens de mercado ou financeiras ${ }^{14}$.

\footnotetext{
13 Paola Antonelli é curadora do Departamento de Arquitetura e Design do MoMA desde 1994, formada em arquitetura pela Universidade Politécnica de Milão, atuou como escritora nas revistas como Domus e Abitare. Em 2016 foi entrevistada pela autora e Luís Michel, em depoimento à autora publicado na Revista Risco 16(1), p.116-21, no qual analisa os aspectos positivos e negativos em estar numa instituição como o MoMA, entre outros assuntos versou sobre curadoria em design e arquitetura, projetos bem e mal sucedidos (Ruggiero, A.; Michel, L., 2018).

14 Mencionaria no contexto nacional e da cidade de São Paulo o Museu de Arte Contemporânea da Universidade de São Paulo (MAC-USP), um museu universitário cujo trabalho muitas vezes está vinculado à pesquisa, ensino e extensão. Em entrevista com a curadora Cristina Freire, ocorrida em 27 março de 2018, ela mencionou a liberdade em pesquisa sobre documentos do arquivo do museu, que resultou em extenso trabalho de identificação de artistas e obras, hoje
} 
A exposição de arte ao ser definida enquanto "máquina interpretativa"15 denota ser um aparato complexo, permite a partir dela certo emaranhado de leituras múltiplas, com todos os componentes sociais envolvidos na arte. De acordo com o Historiador Jean-Marc Poinsot (2014, p.11), há uma mudança sobre a leitura das exposições, alterando-se de uma narrativa tradicional aproximada aos salões, organização institucional, obras expostas e recepção critica, para uma outra abordagem do objeto em exposição, em que pesem as modificações referentes ao tempo, ao espaço, à sociabilidade da exposição como formato de trabalho e à própria interação entre os seus agentes produtores: artistas, instituições, curadores, público, produção de valores.

Do encontro entre áreas interpretativas (história da filosofia, história da literatura e história das ciências) e da história dos objetos e das práticas (história cultural), Roger Chartier (2007, p.24) atribui um duplo movimento, de um lado o reconhecimento da importância da historicidade das operações, atores, lugares, produção, transmissão e recepção das obras pelas interpretativas; e um retorno às obra, textos, formas de transmissão dos escritos e contextos políticos, sociais, econômicos, estéticos que regem a produção, circulação e recepção das obras, pela história cultural. Neste encontro, questões comuns afloraram na ordem das variações conceituais, movimentos, classificação, descontinuidade nas categorias, que permitem produzir e compreender a cultura escrita e a historicidade da materialidade, significados decorrentes das técnicas de produção, circulação, transmissão do

reconhecido internacionalmente, sobre a rede dos artistas conceituais que atuaram em diálogos com o MAC nos anos da ditadura brasileira e da América Latina.

15 Jean Marc-Poinsot, foi professor da Universidade de Haute-Bretagne Rennes na França, fundador e presidente dos arquivos da crítica de arte, hoje sediado em Rennes. Autor de numerosas publicações, entre elas L'Atelier sans mur. Textes, 1978-1990, Villeurbanne : Art éditions, 1991 e Quand lóuvre a lieu: l'art exposé et ses récits autorisés. Les presses du réel, 1999. Foi editor dos Escritos de Daniel Buren (1965-1990), 3 vol. Bordeaux: Centre d'Art Plastique Contemporain, Musée d'Art Contemporain, 1991. 
manuscrito, impresso, leituras em voz alta, outras oralidades, da recepção entre tantas. $^{16}$

A exposição enquanto máquina interpretativa (Poinsot) funciona como um dispositivo aos agentes envolvidos, desde os produtores, curadores, artistas, diretores e os receptores, público em geral, todos jogadores cujas posições e hierarquias por vezes embaralham-se por trocas em tempos e contextos distintos. Vozes dissonantes em tensão e disputas por condutas, gestos, produção de valor e história. Um dos aspectos a ser investigado, a quem atribuir autoria de uma exposição? Ao artista? Ao curador? À Instituição? Ao Mercado? Toda curadoria de exposição consiste em um trabalho de problematização? A quem cabe a interpretação, ao curador ou ao público, ou seria ao diálogo entre todos os atores do sistema? A exposição, assim como a obra, somente acontece na ausência do autor ou do curador? A subjetividade está no artista, curador, na instituição ou no público? Neste jogo, há uma hierarquia entre os participantes? Sobre esta última questão, o depoimento de Michele Millar Fischer ${ }^{17}$ assinala aquela existente no trabalho do curador e sua posição no MoMA, "no museu a pessoa mais importante é o curador. Às vezes o artista é a pessoa mais importante, mas há um forte agenciamento para que a última palavra seja do curador".

\section{Materialidade, gesto/nexo e público}

O contato e a proximidade com a obra originam a fruição pelo convívio. 0 senso de responsabilidade em trabalhar com a curadoria, mais do que cuidar

\footnotetext{
16 A exposição "Mulheres Radicais", que ocupou a Pinacoteca do Estado de São Paulo em 2018, contempla alguns pontos levantados por Roger Chartier, como a historicidade das ações, quando reúne conjunto de obras em que o corpo feminino, a violência e o preconceito, como temáticas de obras realizadas entre 1965 e 1980, cuja abordagem se projeta integralmente aos debates do momento, como na ocasião a marcha feminina contra o candidato à presidência. https://epoca.globo.com/em-protesto-multicolorido-manifestantes-dizem-elenao-contra-bolsonaro-nolargo-da-batata-em-sao-paulo-23113791

${ }^{17}$ Michele Millar Fischer foi assistente de curadoria no MoMA, no Departamento de Arquitetura e Design, atua como professora e assistente curatorial de Artes Decorativas e Design no Museu de Arte da Filadélfia, seu depoimento à autora está publicado na Revista Risco 16(1) p.111 (Ruggiero, A.; Michel, L., 2018).
} 
de uma coleção, está na ação de zelar e promover o legado listado e preservado como patrimônio de culturas variadas, e ao mesmo tempo como carece ser compartilhado de forma crítica e incomum. A curadoria, afirma Juliet Kinchin ${ }^{18}$, comunica conexões e histórias para um amplo segmento, e de uma maneira não verbal, de modo que objetos e imagens dialoguem entre si, criando narrativas que conduzam o espectador ou incitem novas questões. Criar uma exposição implica em formular pontos de vistas e argumentos em uma forma espacial e material, e certamente parte disso seria ter profundo conhecimento para estar apto a tais conexões com saber integro e completo.

A materialidade e o contato do objeto com o público atrai, impulsiona a visitação, estende tipos de espectadores, amplia número de visitantes adquire valor cada vez mais significativo e para além da sociedade do espetáculo, afastada do pensamento e transformação. Separar gesto entre autoria e curadoria evidencia esta enquanto pesquisa aprofundada e integra objetos em amplo processo. Acrescentem-se outras funções, cito acolhimento, documentação, conservação, arquivo, seleção variada de espectadores, vale dizer entrar na esfera conhecida como salvaguarda, de forma a localizar, disponibilizar, ampliar o acervo e criar novas hipóteses críticas sobre a coleção existente, prática encontrada especialmente em museus universitários e públicos $^{19}$. Ação entendida como pensamento que se materializa nas questões, autoria não se reduz a um evento, mas uma série, um tema que permanece, no nexo e no gesto.

Foucault classifica em "fundadores de discursividade" pensadores como Karl Marx e Sigmund Freud, que definem teorias, tradição e disciplina, que ocupam

\footnotetext{
18 Juliet Kinchin curadora da coleção de Arquitetura e Design do Museu de Arte Moderna/MoMA de Nova York, em entrevista à autora realizada em novembro de 2016.

19 Dentre alguns exemplos no campo de instituições públicas ressalto os trabalhos de Maria Cristina Freire no Museu de Arte Contemporânea da Universidade de São Paulo (MAC-USP), de Valéria Piccoli na Pinacoteca do Estado de São Paulo, de Giancarlo Latorraca no Museu da Casa Brasileira entre outros com perfil de pesquisador e curador, assim como Isa Grinspum curadora independente e autora de diversos projetos museológicos, entre eles o Museu da Língua Portuguesa em São Paulo e o Museu Cais do Sertão no Recife.
} 
uma posição "transdiscursiva", já que não encerram um questionamento, tema ou assunto, mas abrem a indefinidos discursos, distintos de um autor literário (Ann Radcliffe). "Eles abriram espaço para outra coisa diferente deles e que, no entanto, pertence ao que eles fundaram" (Foucault, s.d.[1969], p.60). A relevância desta introdução poderia implicar em definir uma "tipologia dos discursos", uma análise histórica, modos, circulação, valorização, atribuição e apropriação de discursos em cada cultura e suas modificações. Lina Bo Bardi seria fundadora de discursividade, na definição de Foucault, certamente seu legado abriu espaço para um universo de probabilidades, tanto no que se refere aos espaços expositivos como na concepção arquitetônica e museológica. ${ }^{20}$

A tese de Roland Barthes em "A morte do autor", sugere que o leitor esteja em posição privilegiada como o receptor e o ativador da escrita, ao invés do autor. O leitor é o "espaço" em que se inscrevem "todas as citações de que é feita a escritura". H.R. Jauss na teoria estética da recepção, também enfatiza o deslocamento para o leitor e receptor da obra, no final dos anos 60. Para esta última pergunta o historiador Francês Jean Marc Poinsot, sugere que a liberdade do espectador somente se constrói limitando o papel do curador "ao de um técnico ou de um assessor de imprensa, (...) O curador renuncia o seu direito de interpretação para libertar seu olhar das exigências da indústria cultural"(2016, p.24).

\footnotetext{
20 O Solar do Unhão na Bahia e o Museu de Arte de São Paulo/MASP, o Serviço Social do Comércio/SESC e as inúmeras exposições que organizou, reunidos na exposição e catálogo "Lina Maneiras de Expor". Existe um sentido de diluição dos dispositivos de expor nos espaço, no caso de Lina Bo Bardi como afirmou Giancarlo Latorraca curador da mostra, revela-se paradoxalmente uma maior densidade material das bases, caixas e prateleiras, cuja simplificação os aproxima ainda mais dos próprios assuntos e objetos expostos. (...) Uma sábia postura da arquiteta em ocultar e jamais sobrepor o desenho elaborado para os suportes sobre o próprio conteúdo. Ela soube marcar a presença necessária, privilegiando o discurso, jamais o meio (Latorraca, 2014, p.17). Grifo nosso.
} 


\section{CONSIDERAÇÕES FINAIS}

[...] o que me impressionava é que o público estava lá, jovens artistas e pessoas que oficialmente não faziam parte do universo artístico da época e estavam fascinadas de verdade. Essas exposições tinham um público humano real. Walter Hopps (1996, p.22)

Ao refletir sobre a autoria e operações nomeadas função-autor e fundador de discursividade, Michel Foucault amplia um horizonte de questões que incitam ponderações sobre os procedimentos em outros meios de linguagem e comunicação. As exposições, enquanto objetos de estudo despertam recentemente atenção em revisões da história intelectual e material, em duplo sentido, narrativas e ocupação dos espaços. A exposição como dispositivo tem potencial interpretativo e serve como indutor e ativador de conteúdos transformadores e críticos para diversos públicos. O curador, entre suas múltiplas tarefas, exerce a função do autor, e ao elaborar seu texto, prezar pela sua ausência seria essencial para que a obra, ou a exposição aconteça. Para que o tema, o assunto, os artistas e o espaço expositivo possam acolher o publico e acioná-lo em inúmeras vias de percepção, aprendizado e deleite. Segundo Agamben, o que garante a vida da obra é a presença "inexpressiva" do gesto do autor, para uma exposição, o curador deveria desaparecer assim como o autor na literatura? No desenvolvimento atual da pesquisa, esta percepção esteve presente em algumas falas de curadores, como já apontado anteriormente $^{21}$, mas ainda um ponto de vista pouco debatido e problematizado perante as demandas e ações institucionais.

Além da autoria, a materialidade de uma exposição, assim como de um livro, modifica e interfere na percepção e modo de recepção do leitor, e do público. O lugar que ficou vazio torna possível a leitura, autor e leitor põem-se em jogo

\footnotetext{
${ }^{21}$ No texto mencionou-se a fala de Barry Bergdoll, destaco aqui ainda a posição da curadora Juliet Kinchin do departamento de A\&D no MoMA, e da curadora da Pinacoteca do Estado de São Paulo Valéria Picolli, em entrevista recente dada à autora.
} 
no texto, assim como espectador e objetos expositivos no espaço. O museu, o seu entorno e o conjunto das obras aliados aos suportes e elementos expográficos configuram o ambiente, a arena deste jogo. Os diálogos, jogadas, embates e rumos decorrentes destes encontros são a essência e a finalidade de todo esforço institucional. Ampliar o vazio é abrir espaço, limitar os direcionamentos, desvanecer vaidades e alargar horizontes, cumprir a função museal, entre outras, de renovar significados, educar.

O nexo e o gesto enquanto componentes da curadoria podem caminhar juntos ou não, o que se coloca enquanto problema volta-se para naturalizar a curadoria como gesto. A não existência do nexo, da pesquisa, do domínio e da materialidade decorre em fragilidade, esvazia sentido e potencialidades. Perceber a possibilidade da função discursiva da curadoria que a exposição exerce, estabelecer o diálogo crítico entre estas instâncias, valorizar o papel principal do público e do receptor, são premissas para abordagens apreciativas de qualidade. O gesto curatorial em evidência distancia-se, assim, cada vez mais de sua origem e propósito, fragiliza a pesquisa em domínio íntegro e crítico do conteúdo, não permite acesso para que se coloque em jogo público e materialidade, o espaço e o conteúdo.

\section{BIBLIOGRAFIA}

Agamben, Giorgio. O Autor Como Gesto. In Profanações. São Paulo: Boitempo; (p.55-64), 2017.

O que é um dispositivo. In: O que é o contemporâneo? E outros ensaios. Trad. Vinícius Nicastro Honesko. Chapecó: Argos; 2009, p. 27-51.

-------. O que é um dispositivo? Outra travessia, Florianópolis, n. 5, p. 9-16, jan. 2005. ISSN 2176-8552. Disponível em: <https://periodicos.ufsc.br/index.php/Outra/article/view/12576/11743 >. Acesso em: 17 ago. 2019. doi:https://doi.org/10.5007/\%x.

Altshuler, Bruce. Introduction. In Dufrêne, B.; Glicenstein, J. Histoire(s). D'Exposition Exhibitions'stories. Paris: Hermann Éditeurs; 2016 
Barthes, Roland. A morte do autor. In: O rumor da Língua. Trad. Mário Laranjeira. São Paulo: Brasiliense, 1988.

Bergdoll, Barry. Curate. Artpaper glossary. Jan/fev. 2015. Disponivel em: https://www.artpapers.org/glossary/curate/

Carvalho AM. A exposição como dispositivo na Arte Contemporânea: conexões entre o técnico e o simbólico. museologia [Internet]. 28nov.2012 acesso em 15set.2019];1(2):47. Available from: http://periodicos.unb.br/index.php/museologia/article/view/12654

Chartier, Roger. O que é um autor? Revisão de uma genealogia. Trad. Luzmara Curcino, Carlos Eduardo Bezerra. São Carlos: Edufscar; 2014.

Firmo, Adrienne de Oliveira. Exposições de arte brasileira: um estudo de exposições como meio para a compreensão dos fundamentos e da recepção da arte contemporânea [tese]. São Paulo: , Faculdade de Arquitetura e Urbanismo; 2017 [citado 2019-09-30]. doi:10.11606/T.16.2018.tde-27062017-144240.

Foucault, Michel. O que é um autor? Trad. Antonio Fernando Cascais. $3^{\mathrm{a}}$ ed. [s.l.]: Vega, [s.d.]. (Passagens; v.6). ISBN 972-699-303-2 . Qu'est-ce qu 'un auteur? In: Bulletin de la societé Française de Philosophie, 63e année, n.3, julliet-septembre 1969, p.73-95

Guasch, Anna Maria. El arte del siglo XX en sus exposiciones: 1945-2007. Barcelona: Ediciones del Serbal, 2009.

Latorraca, Giancarlo. Maneiras de expor: Arquitetura expositiva de Lina Bo Bardi. São Paulo: Museu da Casa Brasileira. 2014.

Poinsot, Jean-Marc. A exposição como máquina interpretativa. In História da Arte em Exposições modos de ver e exibir no Brasil. Cavalcanti, A. Malta, M. Couto, M.F.M. et al. Rio de Janeiro: Rio Books/Fapesp, 2016.

Ruggiero A, Michel L. Interview with Barry Bergdoll. Risco, Rev. Pesqui. Arquit. Urban. [Internet]. 9Jul.2018 [cited 11Sep.2019];16(1):105-14. Disponível em: http://www.revistas.usp.br/risco/article/view/147774

Wall, Jean. Le malheur de la conscience dans la philosophie de Hegel, 1929). https://archive.org/details/in.ernet.dli.2015.188060/page/n19 